\title{
ВПЛИВ ГІПОТЕРМІЧНОГО ЗБЕРІГАННЯ НА ДЕЯКІ ПОКАЗНИКИ ЯКОСТІ ЕРИТРОЦИТВМІСНИХ КОМПОНЕНТІВ ДОНОРСЬКОЇ КРОВІ
}

\author{
Калиниченко Т. О. ${ }^{1}$, Аношина М. Ю. ${ }^{1}$, Білоусов А. М. ${ }^{2,3}$, \\ Малигон О. І. ${ }^{2,3}$, Яговдік М. В. ${ }^{1}$, Парубець Л. І. ${ }^{1}$, \\ Любич В. В. ${ }^{1}$, Лагода А. В. ${ }^{1}$ \\ ${ }^{1}$ ДУ«Інститут гематології та трансфузіологї̈ НАМН України», \\ Київ, Україна \\ ${ }^{2}$ КНП ХОР «Обласний ичентр служби крові», Харків, Україна \\ ${ }^{3}$ Харківська медична академія післядипломної освіти МОЗ Украӥни, \\ Харків, Украӥна
}

\section{Резюме}

Вступ. Дозволені стандарти гіпотермічного зберігання у банках компонентів донорської крові (ДК) при температурі $2-6{ }^{\circ} \mathrm{C}$ не виключають розвитку поступово прогресуючого пошкодження еритроцитів з накопиченням токсичних речовин. Це підвищує ризики післятрансфузійних імунних та запальних ускладнень у реципієнтів. Механізми, пов'язані зі зниженням стабільності клітинних мембран в прочесі зберігання, потребують додаткового вивчення.

Мета - дослідити активність прочесів окислення за маркерами ліпопероксидації в еритроцитвмісних компонентах (ЕВК) периферичної ДК під час тривалого гіпотермічного зберігання та оцінити їхній вплив на якість зазначених консервованих компонентів.

Матеріали і методи. Об'єктом цього дослідження були ЕВК ДК, попередньо заготовлені на консервантах, що дозволені до застосування у виробничій трансфузіологіі. Досліджували активність перекисного окислення ліпідів, каталази, а також інші біохімічні та ичитологічні показники якості зазначених компонентів крові протягом восьми тижнів зберігання при температурі $2-6{ }^{\circ} \mathrm{C}$.

Результати. Зіставлення груп на етапах дослідження підтвердило, що у нормативно дозволені терміни гіпотермічного зберігання у ЕВК ДК відбувається активація процесів окислення. Виявлено численні сильні кореляційні зв'язки показників ліпопероксидаџіï та інших змінних, щзо характеризують стабільність мембран еритроцитів. Складність взаємозв'язків між показниками метаболізму й властивостями еритрочитів обтяжують прогнозування їхньої відповіді на різні умови зберігання.

Висновки. Результати изього дослідження підтверджують обтрунтованість та перспективність подальших кроків, направлених на стабілізацію структури та функиіі мембран еритрочитів, щзо мають здійснюватись шляхом впливу на активність прооксидантних прочесів під час виготовлення ЕВК з ДК. 
Ключові слова: еритроцити, гіпотермічне зберігання, якість компонентів крові, метаболізм, перекисне окислення ліпідів, пошкодження при зберіганні.

\title{
IMPACT OF HYPOTHERMAL STORAGE ON SOME QUALITY INDICATORS OF DONOR BLOOD ERYTHROCYTE-CONTAINING COMPONENTS
}

\author{
T. O. Kalynychenko ${ }^{1}$, M. Yu. Anoshyna ${ }^{1}$, A. N. Belousov ${ }^{2,3}$, O. I. Malygon ${ }^{2,3}$, \\ M. V. Yagovdik ${ }^{1}$, L. I. Parubets ${ }^{1}$, V. V. Liubych ${ }^{1}$, A. V. Lagoda ${ }^{1}$ \\ ${ }^{1}$ SI «Institute of Hematology and Transfusiology of the NAMS of Ukraine», \\ Kyiv, Ukraine \\ ${ }^{2}$ Kharkiv Regional Center of Blood Service, Kharkiv, Ukraine \\ ${ }^{3}$ Kharkiv Medical Academy of Postgraduate Education, Kharkiv, Ukraine
}

\begin{abstract}
Introduction. Permitted standards of conditions for hypothermic storage of donor blood (DB) components in banks at a temperature of $2-6{ }^{\circ} \mathrm{C}$ do not preclude the development of gradually progressive damage to red blood cells (RBCs) and the accumulation of toxic substances, which increases the risk of immune and inflammatory complications of blood transfusion recipients. Processes that affect the stability of cell membranes during storage require further analysis.

The aim of this study was to investigate the activity of oxidative processes by lipid peroxidation (LPo) markers in erythrocyte-containing components (ECCs) of the DBC during long-term hypothermic storage and to evaluate their impact on the quality of these preserved components.

Materials and methods. Erythrocyte-containing blood component, prepared with preservatives approved for use in industrial transfusiology, was the object of this study. The activities of LPo and catalase, as well as other biochemical and cytological indicators of the quality of these blood components, have been studied within eight weeks of storage at the temperature of $2-6^{\circ} \mathrm{C}$.

Results. A step-by-step comparison of the group results of the ECCs study during their hypothermic storage showed the activation of oxidation processes. Numerous strong correlations between indicators characterizing the activity of LPo processes and other variables responsible for the stability of cell membranes have been found. The complexity of the relationship between metabolic parameters and the cell membrane properties significantly complicates the search for ways to improve the technologies for the manufacturing of the ECCs from $D B$.

Conclusions. The results of this study convincingly confirm the validity and prospects of further steps aimed at stabilizing the structure and function of RBCs membranes, which should be carried out by influencing the activity of prooxidant processes during the manufacture of ECC from DC.
\end{abstract}

Keywords: red blood cells, hypothermic storage, quality of blood components, metabolism, lipid peroxidation, storage lesion. 


\section{Вступ}

Трансфузії еритроцитвмісних компонентів (ЕВК) - надважливий елемент у терапії широкого спектру патологічних станів, що супроводжуються анемією тяжкого ступеня. Виробничі операційні процедури виготовлення ЕВК $з$ окремої одиниці консервованої донорської крові передбачають концентрацію еритроцитів з видаленням значної частини плазми. Подальше зберігання компоненту відбувається у спеціальних контейнерах з пластику, що забезпечують газообмін. Фактично всі існуючі та впровадженні розробки у цій галузі спрямовані на стабілізацію мембран еритроцита, підтримку його функціональної активності. Але, на жаль, дозволені стандартами тривалі терміни зберігання (від 21 до 42 діб, в залежності від середовища для консервування) не виключають розвитку поступово прогресуючого пошкодження еритроцитів 3 накопиченням токсичних речовин $[1,2]$. Цей комплекс негативних змін під назвою «пошкодження при зберіганні» має загальні риси активації окислювальних процесів [3], що впливає на цілісність мембран та корелює з ризиком післятрансфузійних імунних та запальних ускладнень у реципієнтів, включно із порушеннями вазорегуляції. Центральною реакцією ініціації розвитку оксидативного стресу при гіпотермічному зберіганні концентрату еритроцитів $є$ хімічне окислення заліза гемоглобіну [1]. При цьому складність взаємозв'язків між показниками метаболізму й збереженістю мембран еритроцитів обтяжують прогнозування їхньої відповіді на різні умови зберігання. Отже, механізми, пов'язані зі зниженням стабільності клітинних мембран в процесі зберігання, ще потребують додаткового вивчення.

Мета - дослідити активність окислювальних процесів за маркерами ліпопероксидації в ЕВК периферичної донорської крові під час тривалого гіпотермічного зберігання та оцінити їхній вплив на якість зазначених консервованих компонентів.

\section{Матеріали і методи}

Досліджували ЕВК, виготовлені за стандартною методикою з периферичної крові здорових донорів, заготовленої на консервантах CPDA-1 (склад: Цитрат-Фосфат-Декстроза-Аденін-1, група-А) та CPD (склад: Цитрат-Фосфат-Декстроза, група-C) (n=12, по 48 досліджень за етапами у кожній з груп). Для ресуспендування еритроцитів використовували стандартний фізіологічний розчин хлориду натрію $0,9 \%$. Концентрати еритроцитів зберігали в умовах гіпотермії (температура $2-6^{\circ} \mathrm{C}$ ) та досліджували 2 непов'язані між собою вибірки на 2, 9, 16, 23, 30, 37, 44, 49-у добу з моменту заготівлі (далі послідовно: I, II, III, IV, V, VI, VII, VIII етапи). 
Активність окислювальних процесів оцінювали за показниками перекісного окислення ліпідів (ПОЛ) з використанням спектрофотометричного методу за Волчегорським I.A. у нашій модифікації [4], що дозволяє диференційоване визначати продукти пероксидації фосфоліпідів (ПОЛф), екстрагованих до ізопропанольної фази, та нейтральних ліпідів (ПОЛн), екстрагованих до гептанової фази. Оптичну щільність кожної фази вимірювали на спектрофотометрі Helios $\alpha$ (Англія) при довжині хвилі $(\lambda)=220$ нм, що відображає вміст ізольованих подвійних зв'язків (ІПЗ) в екстрагованих ненасичених жирних кислотах - субстратах ПОЛ. Концентрацію дієнових кон'югатів (ДК) вимірювали при $\lambda=232$ нм; триєнових (ТК) - при $\lambda=268$ нм, оксодієнових (ОДК) при $\lambda=278$ нм, кінцевих продуктів ПОЛ типу шифових основ (ШО) - при $\lambda=400$ нм. Контролем слугували гептанова та ізопропанольна фази води. Також визначали активність каталази (АК) [5], вміст глюкози [6] та показники перекисної резистентності еритроцитів (ПРЕ) [7].

Оцінку якості ЕВК здійснювали за рядом загальновизнаних показників [8], а саме: вміст еритроцитів визначали у камері Горяєва, кислотність $(\mathrm{pH})$ - за потенціометричним методом [9], вміст вільного гемоглобіну $\left(\mathrm{Hb}_{\mathrm{v}}\right)$ - за спектрофотометричним методом [10]. Показники проникливості еритроцитарних мембран (ПЕМ) встановлювали за відсотком (\%) гемолізу в п'яти точках кривої сечовинного гемолізу (1ПЕМ-5ПЕМ) [11].

Статистичну обробку здійснювали 3 використанням пакету прикладних статистичних програм STATISTICA 6.0 (StatSoft, USA) [12, 13]. Нормальність розподілу кількісних ознак визначали за критерієм Шапіро-Уілка. Використані критерії оцінки значущості відмінностей залежали від нормальності розподілу величин (t-критерій Стьюдента або критерій Манна-Уітні). Міжетапні порівняння медіан (Ме) показників кожної з груп здійснювали за критерієм рангового дисперсійного аналізу Фрідмана з обчисленням коефіцієнта конкордації Кендала (W). Оцінку сили кореляційних взаємозв'язків між змінними проводили за критеріями шкали Чедока.

\section{Результати та їх обговорення}

Статистичний аналіз даних, отриманих на кожному з восьми етапів зберігання ЕВК в умовах гіпотермії у зразках С- та А - груп, дозволив встановити статистично значущу міжгрупову різницю частини показників лише на I-y, V-y та VIII-у етапах дослідження (табл. 2-4; рис. 1-8).

Вже на першу добу зберігання встановлено значущу різницю між групами щодо вмісту вторинних продуктів пероксидації фосфоліпідів (рис. 1, 2). На цьому ж етапі виявлені й відмінності у показниках стійкості мембран еритроцитів до зовнішніх впливів (табл. 1). 


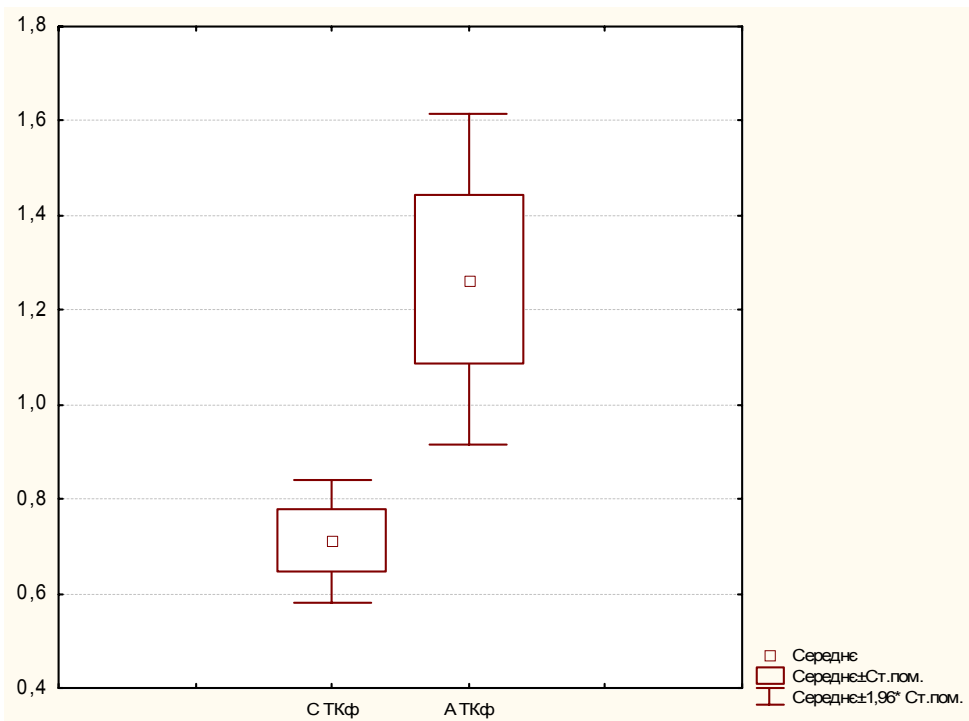

Рисунок 1. Діаграма розмаху середніх показників вмісту триснових кон 'югатів при пероксидачії фосфоліпідів (ТКф) у EBK C-та A-груп на першому етапі гіпотермічного зберігання (1 доба); $t$-критерій Стьюдента, $p 2$-сторонній =0,026)

\section{Таблиця 1. Статистично значуща (критерій Стьюдента) міжгрупова різниця показників ПЕМ у ЕВК на етапах гіпотермічного зберігання}

\begin{tabular}{|c|c|c|c|c|c|c|c|}
\hline Етап & Змінна, \% & Група & $\mathrm{M}$ & $\mathrm{S}$ & $\mathrm{m}$ & $-95 \%$ ДІ & $+95 \%$ ДІ \\
\hline \multirow{4}{*}{ I } & \multirow{2}{*}{ 4ПЕМ } & $\mathrm{C}$ & 83,8 & 4,6 & 1,9 & 79,0 & 88,6 \\
\hline & & A & $90,5^{1}$ & 5,1 & 2,1 & 85,2 & 95,8 \\
\hline & \multirow{2}{*}{ 5ПЕМ } & $\mathrm{C}$ & 89,3 & 3,8 & 1,6 & 85,2 & 93,3 \\
\hline & & A & $95,0^{2}$ & 2,2 & 0,9 & 92,6 & 97,3 \\
\hline \multirow{2}{*}{ V } & \multirow{2}{*}{ 5ПЕМ } & $\mathrm{C}$ & 90,1 & 5,4 & 2,2 & 84,4 & 95,7 \\
\hline & & $\mathrm{A}$ & $96,4^{3}$ & 2,6 & 1,0 & 93,7 & 99,0 \\
\hline
\end{tabular}

Примітки: М - середньоарифметичне значення; s - середньоквадратичне (стандартне) відхилення; $\mathrm{m}$ - стандартна помилка середньоарифметичного значення; ДІ - довірчий інтервал; ПЕМ - проникливість еритроцитарних мембран за показниками 4 (4ПЕМ) та 5 (5ПЕМ) точок кривої сечовинного гемолізу; ${ }^{1}$ - відмінність показників 4 ПЕМ між (C) - та (А) - групами на I етапі спостереження $(\mathrm{p}=0,038){ }^{2}$ - відмінність показників 5 ПЕМ між (C) - та (А) - групами на I етапі спостереження $(\mathrm{p}=0,011){ }^{3}$ - відмінність показників 5 ПЕМ між (C) - та (A) - групами на V етапі спостереження $(\mathrm{p}=0,026)$ 


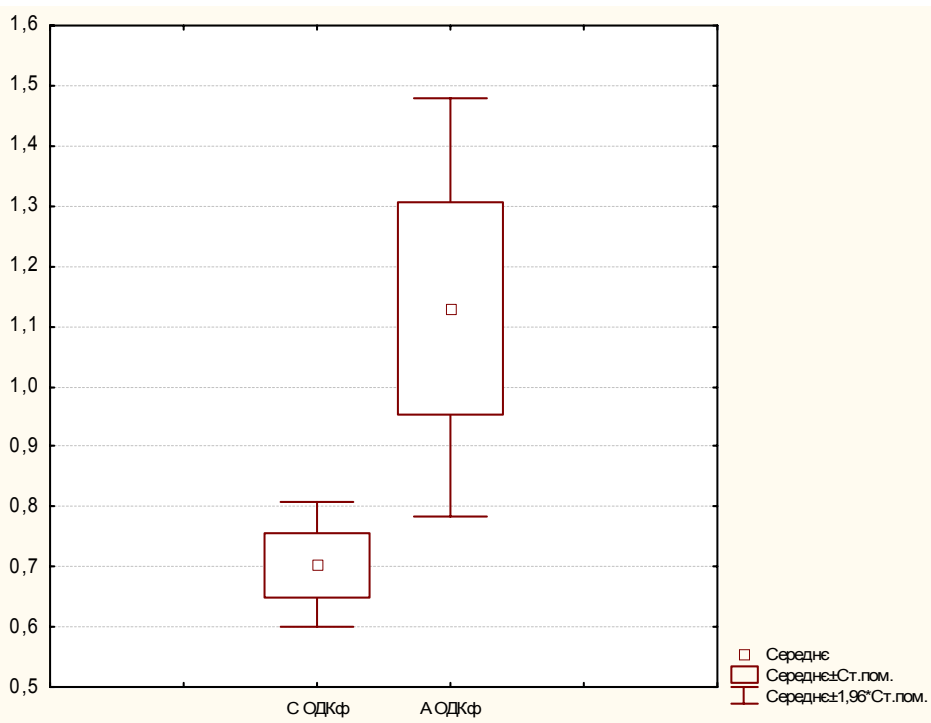

Рисунок 2. Діаграма розмаху середніх показників вмісту оксодієнових кон'югатів при пероксидачії фосфоліпідів (ОДКф) у зразках ЕВК С- та A-груп на першому етапі гіпотермічного зберігання (1 доба); $t$-критерій Стьюдента, $p=0,044$ )

Дані таблиці 1 свідчать про підвищений рівень сечовинного гемолізу у групі А, де зафіксовано значно вищий рівень вторинних продуктів ПОЛ у фракції фосфоліпідів (рис. 1, 2).

На пізніх етапах зберігання (49 діб) різниця у показниках ПОЛ зразків, що зберігали на консервантах CPD та CPDA-1 також була суттєвою (табл. 2).

Таблиця 2. Статистично значуща (за критеріями Стьюдента або

Манна-Уітні) міжгрупова різниця показників ПОЛ у ЕВК на VIII етапі гіпотермічного зберігання

\begin{tabular}{|c|c|c|c|c|c|c|}
\hline \multicolumn{7}{|c|}{ t-критерій Стьюдента } \\
\hline Змінна, Од/мл & Група & $\mathbf{M}$ & $\mathbf{s}$ & $\mathbf{m}$ & $\mathbf{- 9 5 \% ~ Д I ~}$ & $\mathbf{+ 9 5 \%}$ ДI \\
\hline \multirow{2}{*}{ ТКн } & $\mathrm{C}$ & 0,498 & 0,064 & 0,026 & 0,431 & 0,565 \\
\cline { 2 - 7 } & $\mathrm{A}$ & $0,715^{1}$ & 0,189 & 0,077 & 0,517 & 0,913 \\
\hline \multirow{2}{*}{ ДКф } & $\mathrm{C}$ & 2,638 & 0,193 & 0,079 & 2,435 & 2,840 \\
\cline { 2 - 7 } & $\mathrm{A}$ & $3,103^{2}$ & 0,445 & 0,182 & 2,636 & 3,571 \\
\hline \multirow{2}{*}{ ОДКф } & $\mathrm{C}$ & 0,797 & 0,061 & 0,025 & 0,733 & 0,861 \\
\cline { 2 - 7 } & $\mathrm{A}$ & $0,958^{3}$ & 0,125 & 0,051 & 0,826 & 1,089 \\
\hline
\end{tabular}


ГЕМАТОЛОГІЯ І ПЕРЕЛИВАННЯ КРОВІ: МІЖВІДОМЧИЙ ЗБІРНИК, 41, 2021 HEMATOLOGY \& BLOOD TRANSFUSION: INTERDEPARTAMENTAL COLLECTION, 41, 2021

Продовження табл. 2

\begin{tabular}{|c|c|c|c|c|}
\hline \multicolumn{5}{|c|}{ Критерій Манна-Уітні } \\
\hline Змінна & Група & $\mathbf{M e}$ & $\mathbf{2 5} \%$ & $\mathbf{7 5} \%$ \\
\hline \multirow{2}{*}{ ОДКн, Од/мл } & $\mathrm{C}$ & 0,528 & 0,506 & 0,544 \\
\cline { 2 - 5 } & $\mathrm{A}$ & $0,688^{4}$ & 0,608 & 0,762 \\
\hline \multirow{2}{*}{ Ін (ДКн/ІПЗн) } & $\mathrm{C}$ & 0,736 & 0,722 & 0,744 \\
\cline { 2 - 5 } & $\mathrm{A}$ & $0,766^{5}$ & 0,747 & 0,800 \\
\hline \multirow{2}{*}{ ІПЗф, Од/мл } & $\mathrm{C}$ & 3,925 & 3,648 & 4,296 \\
\cline { 2 - 5 } & $\mathrm{A}$ & $4,572^{6}$ & 4,224 & 5,021 \\
\hline
\end{tabular}

Примітки: М - середньоарифметичне значення; s - середньоквадратичне (стандартне) відхилення; $\mathrm{m}$ - стандартна помилка середньоарифметичного значення; ДІ - довірчий інтервал; ТКн, ОДКн - триєнові та оксодієнові кон'югати пероксидації нейтральних ліпідів; Ін (ДКн/ІПЗн) - індекс окислення первинних продуктів пероксидації нейтральних ліпідів; ДКф, ОДКф, ІПЗф - відповідно дієнові та оксодієнові кон'югати, ізольовані подвійні зв'язки пероксидації фосфоліпідів; ${ }^{1}$ - відмінність показників ТКн між (C) - та (А) - групами (p 2 сторонній $=0,023) ;{ }^{2}$ - відмінність показників ДКф між (C) - та (A) - групами $(\mathrm{p}=$ $0,041) ;{ }^{3}$ - відмінність показників ОДКф між (C) - та (А) - групами $(\mathrm{p}=0,018)$; $\mathrm{Me}$ - медіана; $25 \%$ і 75\% - границі процентиль; ${ }^{4}$ - міжгрупова відмінність показників ОДКн $(\mathrm{p}=0,020) ;{ }^{5}$ - міжгрупова відмінність показників Ін $(\mathrm{p}=0,025) ;{ }^{6}$ - міжгрупова відмінність показників ІПЗф $(\mathrm{p}=0,037)$

За критеріями Стьюдента та Манна-Уітні (табл. 2) статистично значущу міжгрупову різницю встановлено для показників на VIII етапі (7 тижнів зберігання). Концентрація продуктів ПОЛ, як і на попередніх етапах, була вищою в групі A, а саме: ТКн - в 1,4 раза, ДКф та ОДКф в 1,2 раза, ОДКн - на $30 \%$, індекс окислення первинних продуктів пероксидації нейтральних ліпідів - майже на 4 \%, субстрати ПОЛ у фракції фосфоліпідів - на $16 \%$.

Хоча показники вмісту еритроцитів (Er) в зразках ЕВК (як між групами на кожному 3 етапів, так і між етапами у кожній з груп) не мали статистично значущої різниці, якість ЕВК з подовженням терміну зберігання значно знижувалась.

Так, порівняння показників ПОЛ між етапами (за критерієм рангового ДА Фрідмана з обчисленням коефіцієнта конкордації Кендала (W)) виявило значну залежність змін від часу перебування в умовах гіпотерміі. Для фракції фосфоліпідів встановлено, що активніше на подовження терміну зберігання реагували зразки групи А, як за кількістю пар (34 з 60 пар, де встановлено підвищення показників, були з групи А), так і за силою зв'язків за коефіцієнтом конкордації Кендала (W) (iз 48 пар із задовільним зв'язком у $34 \mathrm{~W}$ був на рівні 0,643-0,680). 
Окрім того, дослідження вмісту інших змінних, таких як АК та ПРЕ, по мірі подовження часу зберігання також продемонструвало значні відмінності, які у всіх виявлених парах (АК - 19 пар і ПРЕ - 47 пар) були статистично значущими $(\mathrm{p}=0,028)$. 319 пар показників АК - 10 було виявлено в групі C (за коефіцієнтом Кендала ( $\mathrm{W}=0,660)$ - зв'язок задовільний). Найвище зростання активності каталази, у порівнянні 3 першими трьома етапами (від 48,5 до 41,7 \%), було відмічено на 49 добу (VIII-ий етап). В групі А визначено 7 пар, що показали підвищення рівня ферменту: на VIII-му етапі відносно I-го - на 11,8 \%, а порівняно з II-им етапом - від 3,0\% до 15, 2 \% (по мірі подовження терміну зберігання ( $\mathrm{W}=0,760$, сильний зв'язок)).

Показники ПРЕ, в залежності від розчину, який застосовувався, й тривалості зберігання, були розбіжними у 47 парах, 21 з яких належала до групи С. Показник з подовженням зберігання зростав на $1,4-28,3 \%$ ( $\mathrm{W}=0,910$, зв'язок сильний). У 17 парах, що належали до групи $\mathrm{A}$, встановлено підвищення від 3,8 до $16,8 \%(\mathrm{~W}=0,741$, зв'язок сильний). 9 пар за обчисленим коефіцієнтом співвідношенням показника ПРЕ у групах C і А показали статистично значиму різницю між етапами у $3,5-$ $9,0 \%(\mathrm{~W}=0,607$, зв'язок задовільний $)$.

Також у всіх зразках по мірі збільшення терміну зберігання в умовах гіпотермії виявлено значне зниження рівня глюкози та збільшення вмісту $\mathrm{Hb}_{\mathrm{v}}$ (за рівнем глюкози - 22 пари у групі С і 23 пари в групі $\mathrm{A}, \mathrm{p}=0,028$; за рівнем $\mathrm{Hb}_{\mathrm{v}}-23$ пари у групі C і 25 пар в групі $\left.\mathrm{A}, \mathrm{p}=0,028\right)$. Найбільша різниця показників вмісту як глюкози, так і $\mathrm{Hb}_{\mathrm{v}}$ спостерігалася між першим і сьомим та першим і восьмим етапами. У групі $\mathrm{C}$ зміни відбувались наступним чином: рівень глюкози падав відповідно в 3,6 та в 4,4 раза ( $\mathrm{W}=0,902$, сильний зв'язок); рівень $\mathrm{Hb}_{\mathrm{v}}$ зростав відповідно в 12,5 та в 14,2 раза, $(\mathrm{W}=0,972$, зв'язок сильний). У групі А також рівень глюкози знижувався в 2,8 та в 5,1 раза ( $\mathrm{W}=0,953$, сильний зв'язок), рівень $\mathrm{Hb}_{\mathrm{v}}$ зростав у 9,6-9,7 раза ( $\mathrm{W}=0,973$, сильний зв'язок). Етапи $\mathrm{V}$-й та VIII-й у групі C мали статистично значущу відмінність з різницею між показниками глюкози в 2,2 раза ( $\mathrm{W}=0,902$, зв'язок сильний). Відмінність між VI-им і VIII-им та VII-им і VIII-им етапами у групі А складала відповідно: за рівнем глюкози - 2,0 та 1,8 раза, $(\mathrm{W}=0,953$, зв'язок сильний), за рівнем $\mathrm{Hb}_{\mathrm{v}}$ у обох випадках $-1,6$ раза $(\mathrm{W}=0,973$, зв'язок сильний).

Прогнозовано негативний вплив на стійкість мембран еритроцитів 3 подовженням термінів зберігання ЕВК був підтверджений показниками ПЕМ. Так, при проведенні статистичного аналізу було виявлено 30 пар зразків, що мали значущу $(\mathrm{p}=0,028)$ міжетапну різницю даних за їхніми 
медіанами, отриманими у першій точці кривої сечовинного гемолізу (1ПЕМ), 12 з цих пар відносились до групи C (W=0,749, зв'язок сильний), а 18 - до групи А (W = 0,826, зв'язок сильний). Показники в 12 зразках ЕВК групи С мали статистично значуще підвищення відносно першого етапу зі збільшенням при подовженні тривалості зберігання в умовах гіпотермії від 1,9 раза на III-му етапі (2 тижні зберігання) до 4,6 раза - на VIII-му етапі (7 тижнів зберігання). У 18 парах зразків групи А зростання показників 1ПЕМ відбувалось у 2,0-3,4 раза (W = 0,826, зв’язок сильний).

Також було виявлено 18 пар, що мали статистично значущу $(\mathrm{p}=0,028)$ міжетапну різницю за медіанами даних, отриманих у другій точці кривої сечовинного гемолізу (2ПЕМ). При цьому до обох груп належала однакова кількість зафіксованих пар (по 9 пар), де зв'язок був кваліфікований як задовільний, а саме: в групі $\mathrm{C}-\mathrm{W}=0,602$, в групі $\mathrm{A}-\mathrm{W}=0,551$. Медіани в інших точках кривої сечовинного гемолізу (3ПЕМ, 4ПЕМ і 5ПЕМ) мали статистично значущі відмінності щодо термінів зберігання тільки для зразків групи С ( $\mathrm{p}=0,028)$.

Проведений кореляційний аналіз дозволив встановити зв'язки між показниками ПОЛ та іншими параметрами якості ЕВК. Так, вже на першому етапі зберігання у групі С були встановлені обернені тісні та дуже тісні зв'язки між вмістом ІПЗн, ДКн, індексом окислення первинних продуктів перокидації (ДКн/ ІПЗн) та рівенем $\mathrm{Hb}_{\mathrm{v}}$ (відповідно: $\mathrm{r}=-0,873$, $\mathrm{p}<0,05 ; \mathrm{r}=-0,932, \mathrm{p}<0,01 ; \mathrm{r}=-0,815, \mathrm{p}<0,05)$, а також прямі тісні кореляційні зв'язки між ІПЗф, ТКф та вмістом АК (відповідно: $\mathrm{r}=0,828$, $\mathrm{p}<0,05 ; \mathrm{r}=0,844, \mathrm{p}<0,05)$. Також на цьому етапі існували взаємозв'язки між показниками якості ЕВК і ПЕМ (між ДКф і 4ПЕМ - r = -0,815, p < 0,05; AK i 2 ПЕМ $-\mathrm{r}=-0,938, \mathrm{p}<0,01$; АК i 3ПЕM $-\mathrm{r}=-0,957, \mathrm{p}<0,01$; АК i 2ПЕМ - r $=-0,814, \mathrm{p}<0,05 ; \mathrm{pH}$ i 4ПЕМ - r=-0,815, $\mathrm{p}<0,05)$. Взаємо3в'язки між ПОЛ та цими показниками якості були наявними на III етапі дослідження (ТКн та $\mathrm{Hb}_{\mathrm{v}}-\mathrm{r}=-0,832, \mathrm{p}<0,05 ;$ ОДКн та $\mathrm{Hb}_{\mathrm{v}}-\mathrm{r}=-0,858$, $\mathrm{p}<0,05$; ШОф та АК $-\mathrm{r}=0,901, \mathrm{p}<0,05$; ТКн і 2 ПЕМ $-\mathrm{r}=-0,856$, $\mathrm{p}<0,05$; ОДКн і 2 ОЕМ - r $=-0,823, \mathrm{p}<0,05$; ТКф і 2 ПЕМ $-\mathrm{r}=-0,837$, $\mathrm{p}<0,05$; ОДКф і 2ПЕМ - r $=-0,859, \mathrm{p}<0,05$;). Наступний IV етап показав ще більше кореляції високих ступенів зв'язку між показниками ПОЛ та вмістом АК, глюкози, Er, показниками pH, ПРЕ, ПЕМ, а саме: між ШОн і $\mathrm{AК}-\mathrm{r}=0,928, \mathrm{p}<0,01$; ІПЗн і ПРЕ - r $=-0,912, \mathrm{p}<0,01$; ДКн і ПРЕ $\mathrm{r}=-0,905, \mathrm{p}<0,01$; ТКн і ПРЕ $-\mathrm{r}=-0,863, \mathrm{p}<0,05$; ОДКн і ПРЕ $-\mathrm{r}=-0,892$, $\mathrm{p}<0,05$; ІПЗф і ПРЕ $-\mathrm{r}=-0,896, \mathrm{p}<0,05$; ДКф і ПРЕ $-\mathrm{r}=-0,924, \mathrm{p}<0,01$; ТКф і ПРЕ - r = -0,857, p < 0,05; ОДКф і ПРЕ - r = -0,877, p < 0,05; ШОн i глюкоза $-\mathrm{r}=0,925, \mathrm{p}<0,01$; АК і глюкоза $-\mathrm{r}=0,932, \mathrm{p}<0,01$; ІПЗф і $\mathrm{pH}$ 
$-\mathrm{r}=0,845, \mathrm{p}<0,05 ;$ ТКф і $\mathrm{pH}-\mathrm{r}=0,859, \mathrm{p}<0,05 ;$ ОДКф і $\mathrm{pH}-\mathrm{r}=0,848$, $\mathrm{p}<0,05 ;$ ІПЗн і 2ПЕМ - r $=-0,822, \mathrm{p}<0,05 ;$ ДКн і 2ПЕМ $-\mathrm{r}=-0,844$, $\mathrm{p}<0,05$; ТКн і 2 ПЕМ $-\mathrm{r}=-0,890, \mathrm{p}<0,05$; ОДКн і 2ПЕМ $-\mathrm{r}=-0,905$, $\mathrm{p}<0,01$; ДКф і 2ПЕМ - $\mathrm{r}=-0,848, \mathrm{p}<0,05$; ОДКф і 2ПЕМ - $\mathrm{r}=-0,830$, $\mathrm{p}<0,05$; ПРЕ і 2ПЕМ $-\mathrm{r}=0,938, \mathrm{p}<0,01 ; \mathrm{Hb}_{\mathrm{v}}$ i $3 \Pi Е M-\mathrm{r}=-0,854$, $\mathrm{p}<0,05$; глюкоза і 3ПЕМ $-\mathrm{r}=-0,927, \mathrm{p}<0,01$. На послідуючих V-му, VI-мy, VII-му і VIII-му етапах сила зв'язків між показниками ліпопероксидації та збереженості еритроцитів не змінювалась: V етап - між ШОф і АК $-\mathrm{r}=0,917, \mathrm{p}<0,01$; ІПЗн і $\mathrm{Hb}_{\mathrm{v}}-\mathrm{r}=0,869, \mathrm{p}<0,05$; ОДКн і $\mathrm{Hb}_{\mathrm{v}}$ $-\mathrm{r}=0,816, \mathrm{p}<0,05$; ІПЗф і $\mathrm{Hb}_{\mathrm{v}}-\mathrm{r}=0,813, \mathrm{p}<0,05$; ПРЕ i $\mathrm{pH}-\mathrm{r}=-0,812$, $\mathrm{p}<0,05$; АК і $\mathrm{pH}-\mathrm{r}=-0,812, \mathrm{p}<0,05$; VI етап - між ШОн і ПРЕ $-r=-0,871, p<0,05$; ШОн і 1ПЕМ $-r=-0,909, p<0,01$; ШОн і 5ПЕМ $-\mathrm{r}=-0,925, \mathrm{p}<0,01$; ТКф і 1ПЕМ $-\mathrm{r}=-0,818, \mathrm{p}<0,05$; ШОф і 1ПЕМ $-\mathrm{r}=-0,930, \mathrm{p}<0,01$; ШОф i 2 ПЕМ $-\mathrm{r}=-0,836, \mathrm{p}<0,05$; АК і 4ПЕМ $-\mathrm{r}=-0,877, \mathrm{p}<0,05$; ПРЕ і 2ПЕМ $-\mathrm{r}=0,814, \mathrm{p}<0,05$; VII етап - між ШОн і ПРЕ - r $=-0,878, p<0,05$; ШОф і ПРЕ $-r=-0,845, p<0,05$; ІПЗф i $1 П Е M-r=-0,904, p<0,01$; ДКф і 1ПЕМ - r = -0,938, p < 0,01; ТКф i 1 1ПЕМ - r = - 0,926, p < 0,01; ОДКф і 1ПЕМ - r = -0,868, $\mathrm{p}<0,05$; ДКф i 2ПЕМ - r $=-0,827, \mathrm{p}<0,05$; VIII етап - між ІПЗн і $\mathrm{Hb}_{\mathrm{v}}-\mathrm{r}=-0,899, \mathrm{p}<$ 0,01; ДКн і $\mathrm{Hb}_{\mathrm{v}}-\mathrm{r}=-0,873, \mathrm{p}<0,05$; ТКн і $\mathrm{Hb}_{\mathrm{v}}-\mathrm{r}=-0,868, \mathrm{p}<0,05 ;$ ОДКн i $\mathrm{Hb}_{\mathrm{v}}-\mathrm{r}=-0,949, \mathrm{p}<0,01$; ТКн і глюкоза $-\mathrm{r}=-0,845, \mathrm{p}<0,05$; ОДКн і глюкоза $-\mathrm{r}=-0,931, \mathrm{p}<0,05$; ОДКф і ПРЕ $-\mathrm{r}=0,936, \mathrm{p}<0,01$; ТКф і АК $-\mathrm{r}=0,975, \mathrm{p}<0,001$; ІПЗф $\mathrm{i}$ Er $-\mathrm{r}=0,812, \mathrm{p}<0,05$; ПРЕ i 3ПЕМ $-r=0,838, p<0,05$; ПРЕ i 4 ПЕМ $-r=0,857, p<0,05$; ПРЕ i 5ПЕМ $-\mathrm{r}=0,832, \mathrm{p}<0,05$.

Численні сильні кореляційні зв'язки показників ліпопероксидації та інших змінних, що характеризують якість ЕВК, також були виявлені і у групі А. Вже на першому етапі зберігання показники ТКф і ОДКф корелювали $з$ рівнем АК (коефіцієнти відповідно: $\mathrm{r}=0,824, \mathrm{p}<0,05$; $\mathrm{r}=0,853, \mathrm{p}<0,05)$. Окрім того, були і інші зв'язки: між вмістом глюкози $\mathrm{i}$ АК $-\mathrm{r}=0,951, \mathrm{p}<0,05$; вмістом Еr і індексом ІПЗф/ДКф $-\mathrm{r}=-0,889$, $\mathrm{p}<0,05$; ТКф і 2ПЕМ $-\mathrm{r}=-0,859, \mathrm{p}<0,05$.

На II етапі зберігання вміст глюкози та $\mathrm{pH}$ мали прямий взаємозв'язок високого ступеня з коефіцієнтом $\mathrm{r}=0,853, \mathrm{p}<0,05$. На цьому ж етапі тісні зв'язки були встановлені також і для інших показників, а саме: ІПЗн 3 2 ПЕМ - r $=-0,844, \mathrm{p}<0,05$; ТКн $з$ 2ПЕМ - r = -0,914, $\mathrm{p}<0,01$; ОДКн 3 2 ПЕМ $-\mathrm{r}=-0,930, \mathrm{p}<0,01$; глюкоза з 1 ПЕМ $-\mathrm{r}=-0,840, \mathrm{p}<0,05$; глюкоза 3 2ПЕМ - r = -0,857, p < 0,05; pH з 1ПЕM - r = -0,982, $\mathrm{p}<0,001 ; \mathrm{pH} 3$ $2 \Pi$ ЕM $-\mathrm{r}=-0,821, \mathrm{p}<0,05$. 
Як і в групі C, на наступних етапах зберігання групи A (V-мy, VI-му, VII-му і VIII-му) сила зв'язків між показниками ліпопероксидації та збереженості еритроцитів не зменшувалась: V етап - між ШОф і АК $\mathrm{r}=0,921, \mathrm{p}<0,01$; ШОф i $\mathrm{Hb}_{\mathrm{v}}-\mathrm{r}=0,857, \mathrm{p}<0,05$; ШОф i Er $-\mathrm{r}=-0,833$, $\mathrm{p}<0,05$; АК і $\mathrm{Er}-\mathrm{r}=-0,893, \mathrm{p}<0,05$; VI етап: ШОн і $\mathrm{AK}-\mathrm{r}=-0,868$, $\mathrm{p}<0,05 ; \mathrm{Hb}_{\mathrm{v}}$ i AK $-\mathrm{r}=0,859, \mathrm{p}<0,05 ;$ ТКф і ПРЕ $-\mathrm{r}=-0,927, \mathrm{p}<0,01$; ШОф і ПРЕ - r $=-0,845, \mathrm{p}<0,05 ;$ АК і $\mathrm{Hb}_{\mathrm{v}}-\mathrm{r}=0,854, \mathrm{p}<0,05$; ІПЗн і 5ПЕМ - r $=-0,982, \mathrm{p}<0,001$; ДКн і 5ПЕМ $-\mathrm{r}=-0,972, \mathrm{p}<0,001$; ТКн i $5 П Е М-r=-0,939, p<0,01$; ОДКн і $5 П Е М-r=-0,985, p<0,001$; ІПЗф i 5ПЕМ $-\mathrm{r}=-0,993, \mathrm{p}<0,001$; ДКф і 5ПЕМ $-\mathrm{r}=-0,962, \mathrm{p}<0,01$; ОДКф i 5ПЕМ $-\mathrm{r}=-0,893, \mathrm{p}<0,05$; VII етап - між ТКф і ПРЕ $-\mathrm{r}=-0,923$, $\mathrm{p}<0,01 ; \mathrm{Hb}_{\mathrm{v}}$ i $\mathrm{AK}-\mathrm{r}=0,837, \mathrm{p}<0,05$; ОДКф i $\mathrm{Er}-\mathrm{r}=-0,864, \mathrm{p}<0,05$; ДКн і 4ПЕМ - r $=-0,813, \mathrm{p}<0,05$; ТКн і 4ПЕМ - r $=-0,840, \mathrm{p}<0,05$; ОДКн i 4 ПЕМ - r $=-0,825, \mathrm{p}<0,05$; ШОн і 4ПЕМ $-\mathrm{r}=-0,866, \mathrm{p}<0,05$; ТКф i 4ПЕМ $-\mathrm{r}=-0,893, \mathrm{p}<0,05$; ОДКф і 4ПЕМ $-\mathrm{r}=-0,893, \mathrm{p}<0,01$; ІПЗн $\mathrm{i}$ 5ПЕМ $-\mathrm{r}=-0,994, \mathrm{p}<0,001$; ДКн і 5ПЕМ $-\mathrm{r}=-0,995, \mathrm{p}<0,001$; ТКн i 5ПЕМ $-\mathrm{r}=-0,993, \mathrm{p}<0,001$; ОДКн і 5ПЕМ $-\mathrm{r}=-0,996, \mathrm{p}<0,001$; ІПЗф $\mathrm{i}$ 5ПЕМ - r $=-0,963, \mathrm{p}<0,01$; ДКф і 5ПЕМ $-\mathrm{r}=-0,899, \mathrm{p}<0,05$; ТКф $\mathrm{i}$ 5ПЕМ $-\mathrm{r}=-0,828, \mathrm{p}<0,05$; ОДКф і 5ПЕМ $-\mathrm{r}=-0,964, \mathrm{p}<0,01$; VIII етап - між ІПЗн і $\mathrm{Hb}_{\mathrm{v}}-\mathrm{r}=-0,914, \mathrm{p}<0,01$; ДКн і $\mathrm{Hb}_{\mathrm{v}}-\mathrm{r}=-0,898, \mathrm{p}<0,05$; ТКн i $\mathrm{Hb}_{\mathrm{v}}-\mathrm{r}=-0,877, \mathrm{p}<0,05$; ОДКн і $\mathrm{Hb}_{\mathrm{v}}-\mathrm{r}=-0,903, \mathrm{p}<0,01$; ТКф і ПРЕ $-\mathrm{r}=-0,852, \mathrm{p}<0,05$; ОДКф і ПРЕ $-\mathrm{r}=-0,817, \mathrm{p}<0,05$; ІПЗн і 1ПЕМ $-\mathrm{r}=0,968, \mathrm{p}<0,01$; ДКн і 1ПЕМ $-\mathrm{r}=0,063, \mathrm{p}<0,01$; ТКн і 1ПЕМ $-\mathrm{r}=0,951, \mathrm{p}<0,01$; ОДКн і 1ПЕМ $-\mathrm{r}=0,967, \mathrm{p}<0,01$; АК і 1ПЕМ $-\mathrm{r}=-0,869, \mathrm{p}<0,01 ; \mathrm{Hb}_{\mathrm{v}}$ і 1ПЕM - r = -0,967, $\mathrm{p}<0,001 ;$ ШОн і 1ПЕМ $-\mathrm{r}=-0,869, \mathrm{p}<0,05 ; \mathrm{Hb}_{\mathrm{v}}$ i 2 $П \mathrm{EM}-\mathrm{r}=-0,911, \mathrm{p}<0,01$; ТКф і 3ПЕM $-\mathrm{r}=-0,871$, $\mathrm{p}<0,05$; ТКф i 4ПЕМ $-\mathrm{r}=-0,835, \mathrm{p}<0,05$; ТКф і 5ПЕМ $-\mathrm{r}=-0,877$, $\mathrm{p}<0,05$.

Таким чином, результати досліджень підтверджують, що зниження якості ЕВК донорської периферичної крові відбувається у прямому зв'язку 3 активацією процесів окислення. Зазвичай, на перших етапах зберігання має місце підтримка гомеостазу за допомогою стимуляції антиоксидантного захисту клітин. Але в подальшому, коли природні резерви клітин $є$ вичерпаними, на фоні накопичення токсичних речовин відбувається значне погіршення якості ЕВК зі зниженням резистентності мембран еритроцитів.

Раніше, на прикладі пуповинної крові, нами було показано, що інтенсифікація процесів ПОЛ негативно впливає на адаптаційні можливості еритроцитів при їхньому низькотемпературному консервуванні (при 
температурі мінус $\left.196^{\circ} \mathrm{C}\right)$ [14]. Зокрема, зростання показників пероксиддації фосфоліпідів засвідчує наявність руйнівних процесів у структурному комплексі еритроцитарної мембрани. Це негативно впливає на спромогність клітин до пластичності, порушує активність пов'язаних з мембраною транспортних систем, регуляцію транспорту речовин, викликає іонний дисбаланс, знижує життєздатність еритроцитів та, у кінцевому рахунку, призводить до неефективності та навіть небезпечності використання трансфузіологічного засобу, яким є ЕВК.

Так, є загальновідомим, що трансфузія компонентів крові низької якості загрожує побічними ефектами в організмі реципієнта [15]. Підвищення ризиків розвитку післятрансфузійних ускладнень та інвалідизації при трансфузіях ЕВК із терміном зберігання більше 14 діб (виготовлених за стандартними операційними процедурами) зафіксовані у хворих кардіохірургічного профілю, пацієнтів із політравмами, тяжкохворих осіб [16, 17]. 3 іншого боку, введення нормативів щодо скорочення термінів зберігання еритроцитів прогнозовано спричинить негативні наслідки у вигляді значного дефіциту крові, що $є$ неприйнятним для систем охорони громадського здоров'я.

Результати цього дослідження переконливо підтверджують обгрунтованість та перспективність подальших кроків, направлених на стабілізацію структури та функції мембран еритроцитів, що мають здійснюватись шляхом впливу на активність прооксидантних процесів під час виготовлення ЕВК з донорської крові. При цьому слід зазначити, що вдосконалення методів у зазначеному напрямі виробничої трансфузіології $\epsilon$ нелегким завданням, враховуючи практичну вичерпаність наявного арсеналу засобів (солі $\left(\mathrm{NaCl}, \mathrm{NaHCO}_{3}, \mathrm{Na}_{2} \mathrm{HPO}_{4}\right.$ ), лимонна кислота, цитрат натрію, аденін, глюкоза та ін.), а також їхні композиції) $[18,19]$. Так, окремі лужні добавки не запобігають накопиченню вільних жирних кислот та побічних продуктів окислення [20]. Це зумовлює пошук нових альтернативних технологічних можливостей.

\section{Висновки}

1. Встановлено, що при зберіганні ЕВК в стандартних умовах гіпотермії (температура $2-6^{\circ} \mathrm{C}$ ) відбувається активація процесів пероксидації ліпідів.

2. Наявність тісних кореляційних зв'язків показників перекисного окислення нейтральних ліпідів та фосфоліпідів з основними показниками якості консервованих ЕВК донорської периферичної крові $\left(\mathrm{Hb}_{\mathrm{v}}, \mathrm{pH}\right.$, вміст еритроцитів та глюкози, резистентність мембран еритроцитів (ПРЕ, 
ПЕМ)) підтверджує центральну роль процесів окислення в генезі патофізіологічних змін основної маси еритроцитів у складі даних трансфузіологічних засобів, що має назву «пошкодження при зберіганні».

3. 3 огляду на клінічну значущість ЕВК донорської периферичної крові, вдосконалення технологій їхнього виготовлення є одним 3 пріоритетних напрямів в галузі виробничої трансфузіології, де основної уваги заслуговує розробка способів гальмування процесів окислення.

\section{Література}

1. Yoshida T, Prudent M, D'alessandro A. Red blood cell storage lesion: causes and potential clinical consequences. Blood Transfus. 2019 Jan;17(1):2752. doi: 10.2450/2019.0217-18.

2. Yurkovich JT, Bordbar A, Sigurjónsson ÓE, Palsson BO. Systems biology as an emerging paradigm in transfusion medicine. BMC Syst Biol. 2018 Mar;12(1):31-9. doi.org/10.1186/s12918-018-0558-x

3. Bardyn M, Tissot JD, Prudent M. Oxidative stress and antioxidant defenses during blood processing and storage of erythrocyte concentrates. Transfus Clin Biol. 2018 Feb;25(1): 96-100. doi: 10.1016/j.tracli.2017.08.001

4. Аношина МЮ, Калиниченко ТО, Глухенька ГТ. Оцінка перекисного окислення ліпідів у зразках кріоконсервованої пуповинної крові. Український журнал гематології та трансфузіології.2011;3:12-5.

5. Беркало ЛВ, Бобович ОВ, Боброва НО, Гейко ОО, Кайдашев IП, Куценко ЛВ, та ін. Методи клінічних та експериментальних досліджень в медицині: посібник. Полтава: Полімет; 2003. 320с.

6. Энциклопедия клинических лабораторных тестов; Меньшиков ВВ, редактор пер. с англ. издания: Cli-

\section{Reference}

1. Yoshida T, Prudent M, D'alessandro A. Red blood cell storage lesion: causes and potential clinical consequences. Blood Transfus. 2019 Jan;17(1):2752. doi: 10.2450/2019.0217-18.

2. Yurkovich JT, Bordbar A, Sigurjónsson ÓE, Palsson BO. Systems biology as an emerging paradigm in transfusion medicine. BMC Syst Biol. 2018 Mar;12(1):31-9. doi.org/10.1186/s12918-018-0558-x

3. Bardyn M, Tissot JD, Prudent $M$. Oxidative stress and antioxidant defenses during blood processing and storage of erythrocyte concentrates. Transfus Clin Biol. 2018 Feb;25(1): 96-100. doi: 10.1016/j.tracli.2017.08.001

4. Anoshyna MYu, Kalynychenko TO, Gluhen'ka GT. [Evaluation of lipid peroxidation in samples of cryopreserved umbilical cord blood]. Ukrainian $\mathbf{J}$ of Hematology and Transfusiology.2011;3:12-5 (in Ukrainian).

5. Berkalo LV, Bobovych OV, Bobrova NO, Geiko OO, Kaidashev IP, Kutsenko LV, et al. [Methods of clinical and experimental research in medicine: a guide]. Poltava: Polymet; 2003. 320p. (in Ukrainian).

6. [Encyclopedia of clinical laboratory tests]; Menshikov VV, editor; transl. from English ed: Clinical guide to 
nical guide to laboratory tests; Tietz NW, ed. Москва: «Лабинформ»; $1997.960 \mathrm{c}$.

7. Клінічна лабораторна діагностика. Практичні заняття з клінічної біохімії; Базарнова МА, Гетте ЗП, редактори. Київ: Вища школа; 1994. $432 \mathrm{c}$.

8. Чугрієв АМ, Толстанов ОК, Перехрестенко ПМ, Шатило ВЙ. Контроль якості донорської крові та її компонентів: монографія. Житомир: Полісся; 2011. 368 с.

9. Електрометричний метод визначення активності іонів водню у вигляді водневого показника $\mathrm{pH}$, p. 2.2.3. Державна Фармакопея України. Вид. 1-е / ДП «Науково-експертний фармакопейний центр». Харків : РІРЕГ; 2001. 536 с.

10. Контроль якості еритроцитвмісних середовищ : метод. Рекомендації. Київ: ДУ «Інститут гематології та трансфузіології НАМН України», Житомирський обласний центр крові; 2012: 32.

11. Колмаков ВН, Радченко ВГ. Значение определения проницаемости эритроцитарных мембран (ПЭМ) в диагностике хронических заболеваний печени. Терапевтический архив. 1982;54(2):59-62.

12. Петри А, Сэбин К. Наглядная медицинская статистика: учеб. пособие; Леонова ВП, редактор пер. с англ. Москва: ГЭОТАР-Медиа; 2015. 216 с.

13. Гржибовский АМ, Иванов СИ, Горбатова МА. Сравнение количественных данных трех и более парных выборок с использованием программного обеспечения Statisti- laboratory tests; Tietz NW, ed. Moscow: Labinform; 1997. 960 p. (in Russian).

7. [Laboratory diagnosis in the clinic. Practical classes in clinical biochemistry]; Bazarnova MA, Goethe ZP, eds. Kyiv: Vyshcha Shkola; 1994. 432 p. (in Ukrainian).

8. Chugriev AM, Tolstanov OK, Perekhrestenko PM, Shatylo VY. [Quality control of donor blood and its components: monograph]. Zhytomyr: Polissya; 2011. 368 p. (in Ukrainian).

9. [Electrometric method for determining the activity of hydrogen ions in the form of hydrogen $\mathrm{pH}$ ], p. 2.2.3. State Pharmacopoeia of Ukraine. Ed. 1/SI «Scientific and Expert Pharmacopeia Center». Kharkiv: RIREG; 2001.536 p. (in Ukrainian).

10. [Quality control of erythrocyte-containing media: guidelines]. Kyiv: SI «Institute of Hematology and Transfusiology of the National Academy of Medical Sciences of Ukraine», Zhytomyr Regional Blood Center; 2012:32. (in Ukrainian).

11.Kolmakov VN, Radchenko VG. [The value of determining the per. meability of erythrocyte membranes (TEM) in the diagnosis of chronic liver disease]. Ther archive. 1982; 54(2):59-62. (in Russian).

12.Petri A, Sabin K. [Visual medical statistics: textbook. Manual] / trans. from English. Ed. by Leonov VP. 3rd ed., reprint. Moscow: GEOTAR-Media; 2015, 216 p. (in Russian).

13. Grzhibovsky AM, Ivanov SI, Gorbatova MA. [Comparison of quantitative data of three or more paired samples using Statistica and SPSS software: parametric and nonpara- 
са и SPSS: параметрические и непараметрические критерии. Наука и Здравоохранение. 2016;5:5-29.

14. Калиниченко ТО, Аношина МЮ, Глухенька ГТ, Алгазінова МК. Еритроцити пуповинної крові як об'єкт довгострокового зберігання при наднизькій температурі. Збірник наукових праць спів робітників НМАПО ім. ПЛ Шупика. 2014; 23(2):515-21.

https://nmapo.edu.ua/zagruzka/zborn ikNMAPO23_4.pdf

15. Yurkovich JT, Zielinski DC, Yang L, Paglia G, Rolfsson O, Sigurjónsson ÓE, Broddrick JT, Bordbar A, Wichuk K, Brynjólfsson S, Palsson S, Gudmundsson S, Palsson BO. Quantitative time-course metabolomics in human red blood cells reveal the temperature dependence of human metabolic networks. J Biol Chem. 2017 Dec 1;292(48):19556-19564. doi: 10.1074/jbc.M117.804914.

16. Zimrin AB, Hess JR. Current issues relating to the transfusion of stored red blood cells. Vox Sang. 2009 Feb; 96(2):93-103. doi: 10.1111/j.1423-0410.2008.01117.x

17. Wang D, Sun J, Solomon SB, Klein HG, Natanson C. Transfusion of older stored blood and risk of death: a meta-analysis. Transfusion. 2012 Jun;52(6):1184-95.

doi: 10.1111/j.1537-2995.2011.03466.x Epub 2011 Dec 21. PMID: 22188419; PMCID: PMC3883449.

18. Hess JR; Biomedical Excellence for Safer Transfusion (BEST) Collaborative. Scientific problems in the regulation of red blood cell products. Transfusion. 2012 Aug;52(8):1827-35. doi: 10.1111/j.1537-2995.2011.03511.x metric criteria]. Science and Healthcare. 2016;5:5-29. (in Russian).

14. Kalynychenko TO, Anoshyna MYu, Hlukhen'ka HT, Algazinova MK. Umbilical cord blood red cells as an object for long-term storage at ultrajow temperature. Collection of Scientific Works of Staff Members of NMAPE.2014;23(2):515-21 (in Ukrainian).

https://nmapo.edu.ua/zagruzka/zborn ikNMAPO23_4.pdf

15. Yurkovich JT, Zielinski DC, Yang L, Paglia G, Rolfsson O, Sigurjónsson ÓE, Broddrick JT, Bordbar A, Wichuk K, Brynjólfsson S, Palsson S, Gudmundsson S, Palsson BO. Quantita tive time-course metabolomics in human red blood cells reveal the temperature dependence of human metabolic networks. J Biol Chem. 2017 Dec 1;292(48):19556-19564. doi: 10.1074/jbc.M117.804914.

16. Zimrin AB, Hess JR. Current issues relating to the transfusion of stored red blood cells. Vox Sang. 2009 Feb; 96(2):93-103.

doi: 10.1111/j.1423-0410.2008.01117.x

17. Wang D, Sun J, Solomon SB, Klein HG, Natanson C. Transfusion of older stored blood and risk of death: a meta-analysis. Transfusion. 2012 Jun;52(6):1184-95.

doi: 10.1111/j.1537-2995.2011. 03466.x Epub 2011 Dec 21. PMID: 22188419; PMCID: PMC3883449.

18. Hess JR; Biomedical Excellence for Safer Transfusion (BEST) Collaborative. Scientific problems in the regulation of red blood cell products. Transfusion. $2012 \mathrm{Aug}$;52(8):1827-35. doi: 10.1111/j.1537-2995.2011.03511.x 
19. McAteer MJ, Dumont LJ, Cancelas J, Rugg N, Vassallo R, Whitley P, Graminske S, Friedman K. Multiinstitutional randomized control stu. dy of haemolysis in stored red cell units prepared manually or by an automated system. Vox Sang. 2010 Jul 1;99(1):34-43. doi: 10.1111/j.1423-0410.2010.01313.x

20. D'Alessandro A, Reisz JA, CulpHill R, Korsten $H$, van Bruggen $R$, de Korte D. Metabolic effect of alkaline additives and guanosine/ gluconate in storage solutions for red blood cells. Transfusion. 2018 Aug; 58(8):1992-2002.

doi: $10.1111 / \operatorname{trf} .14620$.
19. McAteer MJ, Dumont LJ, Cancelas J, Rugg N, Vassallo R, Whitley P, Graminske S, Friedman K. Multiinstitutional randomized control study of haemolysis in stored red cell units prepared manually or by an automated system. Vox Sang. 2010 Jul 1;99(1):34-43. doi: 10.1111/j.1423-0410.2010.01313.x 20. D'Alessandro A, Reisz JA, CulpHill $\mathrm{R}$, Korsten $\mathrm{H}$, van Bruggen $\mathrm{R}$, de Korte D. Metabolic effect of alkaline additives and guanosine/ gluconate in storage solutions for red blood cells. Transfusion. 2018 Aug; 58(8):1992-2002. doi: $10.1111 / \operatorname{trf} .14620$.

Надійшла: 12.08.2021

Контакти: kalynychenko_tetiana@ukr.net 